\title{
Role of Plants in Biomonitoring Vehicular Emissions
}

\author{
Muninathan N. ${ }^{1}$, Ponnulakshmi R. ${ }^{1}$, Nalini D. ${ }^{1}$, Prathiba S. ${ }^{2}$ \\ ${ }^{1}$ Research Scientist, Central Research Laboratory, Meenakshi Medical College Hospital and Research Institute, \\ Enathur, Kanchipuram, Tamilnadu, India, ${ }^{2}$ Lecturer, Department of Pharmacology, Meenakshi Ammal Dental \\ College and Hospital, Chennai, India
}

\begin{abstract}
Introduction: Air pollution caused by the pollutants present in the atmosphere which is harmful to the environment and the living population. The plants showed stunted growth, animal's causes various form of diseases and the pollutants harmfully affect the human beings by causing respiratory problems and the whole environment is totally affected causing depletion of ozone layer and that directly or indirectly affects the living system present in the environment.
\end{abstract}

Materials and Method: The leaf samples were collected from the Sholinganallur area and authenticated. Later the samples were characterized for morphological characters, pigment analysis, Biochemical parameters and the score of tolerance index of Air pollution was calculated were tabled and graphed as per the standard protocol.

Results: The samples were collected from sholinganallur traffic zonal area and totally 14 leaf samples were gathered from the experimental site and was authenticated. The morphological characters of length and width of leaf samples were calculated and in Biochemical parameters, $\mathrm{pH}$ of leaf, Relative water content and ascorbic acid content showed good activity in evergreen shrub. In pigment analysis of chlorophyll, the maximum and minimum amount was found in evergreen shrub Bougainvillea glabra with $68.72 \mathrm{mg} / \mathrm{g}$ and Tecoma capensis in $14.72 \mathrm{mg} / \mathrm{g}$. The APTI value was maximum and minimum in evergreen shrub Tabernaemontana divaricata with 114.66 and Nerium oleander with 48.05.

Conclusion: The plants found in and around the experimental area possess good activity against the air pollution and these plants can be kept at the roadside to prevent and withstand the air pollution in the environment.

Keywords: Evergreen tree/shrub, air pollution, APTI, vehicular emission

\section{Introduction}

The global impact in change of atmosphere [1] especially in metropolitan cities are due to rapid industrialization and urbanization process causes serious effects of air pollution on both human and plant communities ${ }^{[2]}$. Due to industrialization, urbanization and raising human population ${ }^{[3]}$ vehicles play a predominant role in the transport sector. Approximately $60-70 \%$ of air pollution is produced from cities across the globe by vehicular emissions which are randomly increasing day by day as means of transportations ${ }^{[4]}$.

There are enormous number of pollutants are released from the vehicles are carbon monoxide, particulates, hydrocarbons, heavy metals, nitric oxide, sulphur dioxide and so on ${ }^{[5,6]}$. The emission of oxidized carbon monoxide and hydrocarbons from the fuel is a product of incomplete combustion (i.e) lacks the combustion of air leading to insufficient oxygen and will not form an end product of carbon dioxide $\left(\mathrm{CO}_{2}\right)$. Ground level Ozone (i.e) smog is formed when hydrocarbons combine with nitrogen oxides and sunlight. The smogs are widely spread and major interactable air pollution. Nitric oxide (NO) like hydrocarbons is predominant source in the formation of ozones and produce acid rain ${ }^{[7]}$. This harmful chemical has an adverse effect on soil and plants grown in that area ${ }^{[8]}$. This serious impact on plant health changes the biochemical parameters such as the action 
of enzymes, proteins, pigments, ascorbic acid and sugar contents ${ }^{[9]}$ rate of photosynthesis, seed germination ${ }^{[10]}$.

Leaves are the most receptive part exposed widely to the polluted air causing a change based on its sensitivity ${ }^{[11]}$. On the surface of leaf or on the stomatal pores dust and other particulate matter get adsorbed ${ }^{[12]}$ and such exposed plant shows changes internally and then the plant after severe effect shows external changes like chlorosis, necrosis and epinasty ${ }^{[13]}$ when exposed to air pollution ${ }^{[14]}$. Thus Air pollution tolerance indices were examined for the selected area and these plants are very much useful in afforestation, reforestation and development of green belt.

\section{Materials and Method}

Leaf sample collection: The samples were collected from the experimental sites from the road sides of Mohamed Sathak College of Arts and Science, Sholinganallur, Chennai, Tamil Nadu, India. The study was carried out and samples were collected before the onset of summer season and the plants were selected based on the change in morphology of leaves due to vehicular pollution.

Identification of collected samples: The collected leaf samples were identified based on its morphological characters from the book, Flora of the Presidency of Madras by Gamble, 1847-1925 and the samples were authenticated ${ }^{[15]}$.
Morphological characters of identified plants: The collected leaf samples were identified for its family, common name through previous literatures and morphological characters like leaf length $(\mathrm{cm})$, leaf width $(\mathrm{cm})$, weight of leaf with dust $(\mathrm{mg})$ and without dust $(\mathrm{mg})$ were estimated.

Biochemical parameters: The $\mathrm{pH}$ of the leaf was determined by ${ }^{[16]}$ Krishna Veni, 2014; ${ }^{[17]}$ Prasad and Rao, 1982. Relative water content was determined by Liu and Ding $2008^{[14]}$ and Sen., $1978^{[18]}$. Ascorbic acid content was determined by metaphosphoric acid (5\%)acetic acid (10\%) solution. Total chlorophyll content was performed by the method of Arnon (1949) ${ }^{[8]}$.

Air Pollution Tolerance Indices (APTI): The Air Pollution Tolerance Indices (APTI) were calculated based on Singh and Rao (1983) ${ }^{[19]}$.Results and Discussion

Collection of samples: The leaves were collected from traffic zones of Sholinganallur around the campus of Mohamed Sathak College of Arts and Science, Chennai where vehicular emission was high during the peak hours where most vehicles travel towards the IT parks. The collected mature leaves were stored in a polythene bag for morphological and biochemical analysis.

Identification of collected samples: The collected leaf samples were photographed from the collected sites and authenticated. The list of 14 plants were collected from the experimental site and tabulated (Table 1; Fig 1).

Table 1: List of leaves collected from the experimental site, Sholinganallur, Chennai

\begin{tabular}{|c|l|l|l|}
\hline S.No. & Scientific name & Family & Common name \\
\hline 1 & Tabernaemontana divaricata & Rosaceae & Cherry laurel \\
\hline 2 & Plumeria rubra & Apocynaceae & Red frangipani \\
\hline 3 & Plumeria obtusa & Apocynaceae & Singapore graveyard \\
\hline 4 & Bougainvillea glabra & Nyctaginaceae & Paper flower \\
\hline 5 & Caryota mitis & Arecaceae & Burmese fishtail palm \\
\hline 6 & Caryota urens L. & Arecaceae & Fishtail wine palm \\
\hline 7 & Pongamia pinnata & Fabaceae & Indian beech \\
\hline 8 & Sterculia foetida & Malvaceae & Guiana chestnut \\
\hline 9 & Nerium oleander & Apocynaceae & Oleander \\
\hline 10 & Ficus benghalensis & Moraceae & Banyan \\
\hline 11 & Tecoma capensis & Bignoniaceae & Cape honeysuckle \\
\hline 12 & Spathodea campanulata & Bignoniaceae & African tulip tree \\
\hline 13 & Muntingia calabura & Muntingiaceae & Calabur tree \\
\hline 14 & Tecoma stans & Bignoniaceae & Yellow trumpetbush \\
\hline
\end{tabular}


Categorization of collected leaf samples: The leaf samples from experimental site were collected, identified and authenticated. Based on the literature survey the plants are categorized or grouped into three distinct phase's namely deciduous tree, Evergreen shrub and Evergreen tree. The entire study was distinguished or compared based on these three categories (Table 2).

Table 2: Categorization of collected leaf samples from the experimental site

\begin{tabular}{|c|l|c|}
\hline S.No. & Category of leaf samples & Number of plants \\
\hline 1 & Deciduous tree & 1 \\
\hline 2 & Evergreen shrub & 7 \\
\hline 3 & Evergreen tree & 6 \\
\hline
\end{tabular}

Morphological measeurements of collected leaf samples: The length of the leaf was high in Plumeria obtusa and leaf width was found to be lower when compared to Caryota urens. Similarly, the weight of the leaf was found to have significant changes when weighed with dust and after cleaning the dust (Table 3 ). According to the results obtained, the accumulation of dust was more on leaf surface which indicates the polluted environment in the selected site.

Table 3: Morphological Measurements of the collected leaf samples from experimental site

\begin{tabular}{|c|l|c|c|c|c|}
\hline S.No & Name of the Plants & Leaf Length $(\mathbf{c m})$ & Leaf Breadth (cm) & $\begin{array}{c}\text { Initial Leaf weight } \\
(\mathbf{m g})\end{array}$ & $\begin{array}{c}\text { Final Leaf weight } \\
(\mathbf{m g})\end{array}$ \\
\hline 1. & Tabernaemontana divaricata & 9.3 & 2.7 & 0.3263 & 0.1373 \\
\hline 2. & Plumeria rubra & 23.3 & 10.2 & 11.6983 & 10.5823 \\
\hline 3. & Plumeria obtusa & 28.2 & 7.4 & 8.2523 & 6.3545 \\
\hline 4. & Bougainvillea glabra & 7.2 & 5.2 & 0.5346 & 0.4986 \\
\hline 5. & Caryota mitis & 9.6 & 4.8 & 0.5359 & 0.5021 \\
\hline 6. & Caryota urens L. & 23.1 & 10.4 & 3.9275 & 3.7621 \\
\hline 7. & Pongamia pinnata & 9.9 & 4.2 & 0.2986 & 0.2972 \\
\hline 8. & Sterculia foetida & 13.6 & 6.7 & 0.8601 & 0.7984 \\
\hline 9. & Nerium oleander & 3.9 & 2.6 & 0.0970 & 0.0901 \\
\hline 10. & Ficus benghalensis & 13.9 & 8.9 & 2.3733 & 2.3198 \\
\hline 11. & Tecoma capensis & 20.2 & 7.4 & 2.3783 & 2.3245 \\
\hline 12. & Spathodea campanulata & 13.5 & 4.3 & 0.8845 & 0.7124 \\
\hline 13. & Muntingia calabura & 18.8 & 2.9 & 1.7749 & 0.5939 \\
\hline 14. & Tecoma stans & & & 1.7110 \\
\hline
\end{tabular}

\section{Biochemical parameters of the samples:}

pH: The leaf extract $\mathrm{pH}$ was ranged from acidic condition of 1.19 to slight alkaline condition of 7.82 . From the experimental site only one deciduous tree was found with a $\mathrm{pH}$ of 6.21 from Plumeria rubra (L.). Evergreen shrubs totally 7 are present in experimental site of which maximum acidic condition was present in Bougainvillea glabra of $\mathrm{pH} 1.19$ and minimum acidic condition was found in Tecoma capensis with a $\mathrm{pH}$ of 6.50. Evergreen trees totally 8 are present in experimental site of which maximum acidic condition was present in Muntingia calabura with a $\mathrm{pH}$ of 5.30 and slightly alkaline condition was found in Ficus benghalensis with a pH of 7.82 (Table 4; Graph 1). In a study conducted by Bharti et al., 2017, Ficus benghalensis showed pH of 8.2 where the pollutant converts the hexose present in the plant to ascorbic acid. 
Table 4: pH of the collected leaf samples from the experimental site

\begin{tabular}{|c|l|c|}
\hline S.No. & Name of the Plants & pH value \\
\hline 1 & Tabernaemontana divaricata & 6.05 \\
\hline 2 & Plumeria rubra & 6.21 \\
\hline 3 & Plumeria obtusa & 6.10 \\
\hline 4 & Bougainvillea glabra & 1.19 \\
\hline 5 & Caryota mitis & 6.48 \\
\hline 6 & Caryota urens L. & 5.74 \\
\hline 7 & Pongamia pinnata & 5.65 \\
\hline 8 & Sterculia foetida & 5.76 \\
\hline 9 & Nerium oleander & 5.50 \\
\hline 10 & Ficus benghalensis & 7.82 \\
\hline 11 & Tecoma capensis & 6.50 \\
\hline 12 & Spathodea campanulata & 6.33 \\
\hline 13 & Muntingia calabura & 5.30 \\
\hline 14 & Tecoma stans & 5.78 \\
\hline
\end{tabular}

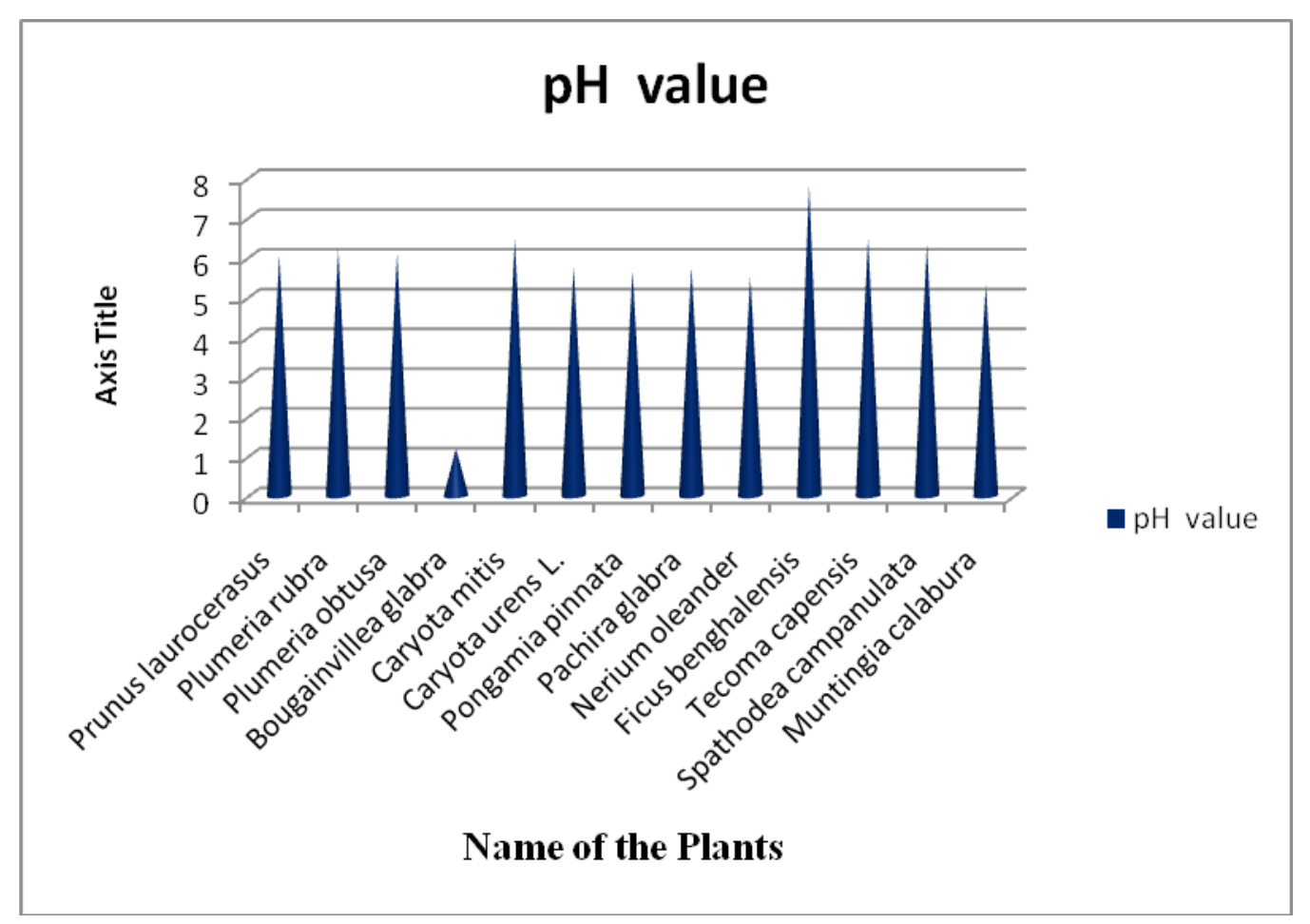

Graph 1. pH level of the collected leaf samples

Relative water content: RWC varied greatly from $13.39 \%$ to $80.78 \%$. RWC in decidious tree was found to have high content of $72.38 \%$. The RWC in evergreen shrub was found to be minimum in Bougainvillea glabra with $13.39 \%$ and maximum in Tecoma capensis with $59.61 \%$. The RWC in evergreen tree was found to be minimum in Spathodea campanulata with $16.94 \%$ and maximum was found in Caryota urens with $80.78 \%$ (Table 5; graph 2). Air pollutant increases the RWC in plants under stress which undergoes the changes in physiological functions during Transpiration and facilitates drought conditions leads to early senescence $^{[20]}$. 
Table 5: RWC of the collected leaf samples from the experimental site.

\begin{tabular}{|c|l|c|}
\hline S.No. & Name of the Plants & RWC \% \\
\hline 1. & Tabernaemontana divaricata & 33.33 \\
\hline 2. & Plumeria rubra & 72.38 \\
\hline 3. & Plumeria obtusa & 57.10 \\
\hline 4. & Bougainvillea glabra & 13.39 \\
\hline 5. & Caryota mitis & 17.93 \\
\hline 6. & Caryota urens L. & 80.78 \\
\hline 7. & Pongamia pinnata & 21.42 \\
\hline 8. & Sterculia foetida & 30.63 \\
\hline 9. & Nerium oleander & 41.66 \\
\hline 10. & Ficus benghalensis & 45.00 \\
\hline 11. & Tecoma capensis & 59.61 \\
\hline 12. & Spathodea campanulata & 16.94 \\
\hline 13. & Muntingia calabura & 20.96 \\
\hline 14. & Tecoma stans & 45.08 \\
\hline
\end{tabular}

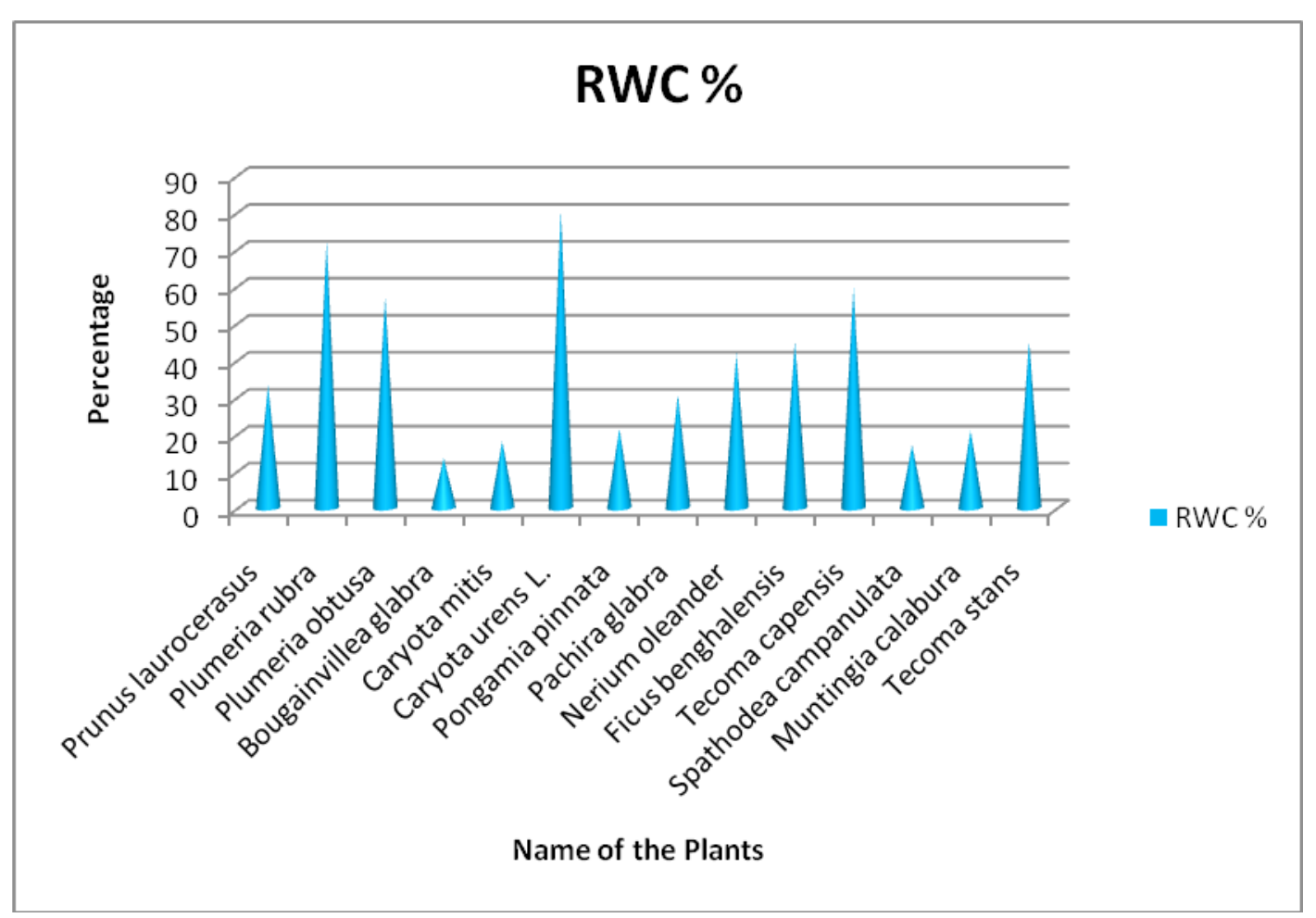

Graph 2. RWC of the plant sample

Estimation of Ascorbic Acid: The Ascorbic acid present was ranged from $12.50 \mathrm{mg} / \mathrm{g}$ to $27.78 \mathrm{mg} / \mathrm{g}$. In deciduous tree Plumeria rubra was found to be 16.59 $\mathrm{mg} / \mathrm{g}$. In evergreen shrub, the ascorbic acid content was minimum in Pongamia pinnata with $12.50 \mathrm{mg} / \mathrm{g}$ and maximum in Tecoma capensis with $27.78 \mathrm{mg} / \mathrm{g}$. In evergreen tree, the presence of Ascorbic acid content was minimum in Sterculia foetida with $14.80 \mathrm{mg} / \mathrm{g}$ and maximum in Spathodea campanulata with $26.67 \mathrm{mg} / \mathrm{g}$ (Table 6; Graph 3). 
Table. 6: Ascorbic acid content of the leaf samples from the experimental site.

\begin{tabular}{|c|l|c|}
\hline S.No. & Name of the Plants & Ascorbic acid mg/g \\
\hline 1. & Tabernaemontana divaricata & 21.89 \\
\hline 2. & Plumeria rubra & 16.59 \\
\hline 3. & Plumeria obtusa & 16.88 \\
\hline 4. & Bougainvillea glabra & 14.45 \\
\hline 5. & Caryota mitis & 17.39 \\
\hline 6. & Caryota urens L. & 20.60 \\
\hline 7. & Pongamia pinnata & 12.50 \\
\hline 8. & Sterculia foetida & 14.80 \\
\hline 9. & Nerium oleander & 13.85 \\
\hline 10. & Ficus benghalensis & 22.48 \\
\hline 11. & Tecoma capensis & 27.78 \\
\hline 12. & Spathodea campanulata & 26.67 \\
\hline 13. & Muntingia calabura & 16.63 \\
\hline 14. & Tecoma stans & 15.80 \\
\hline
\end{tabular}

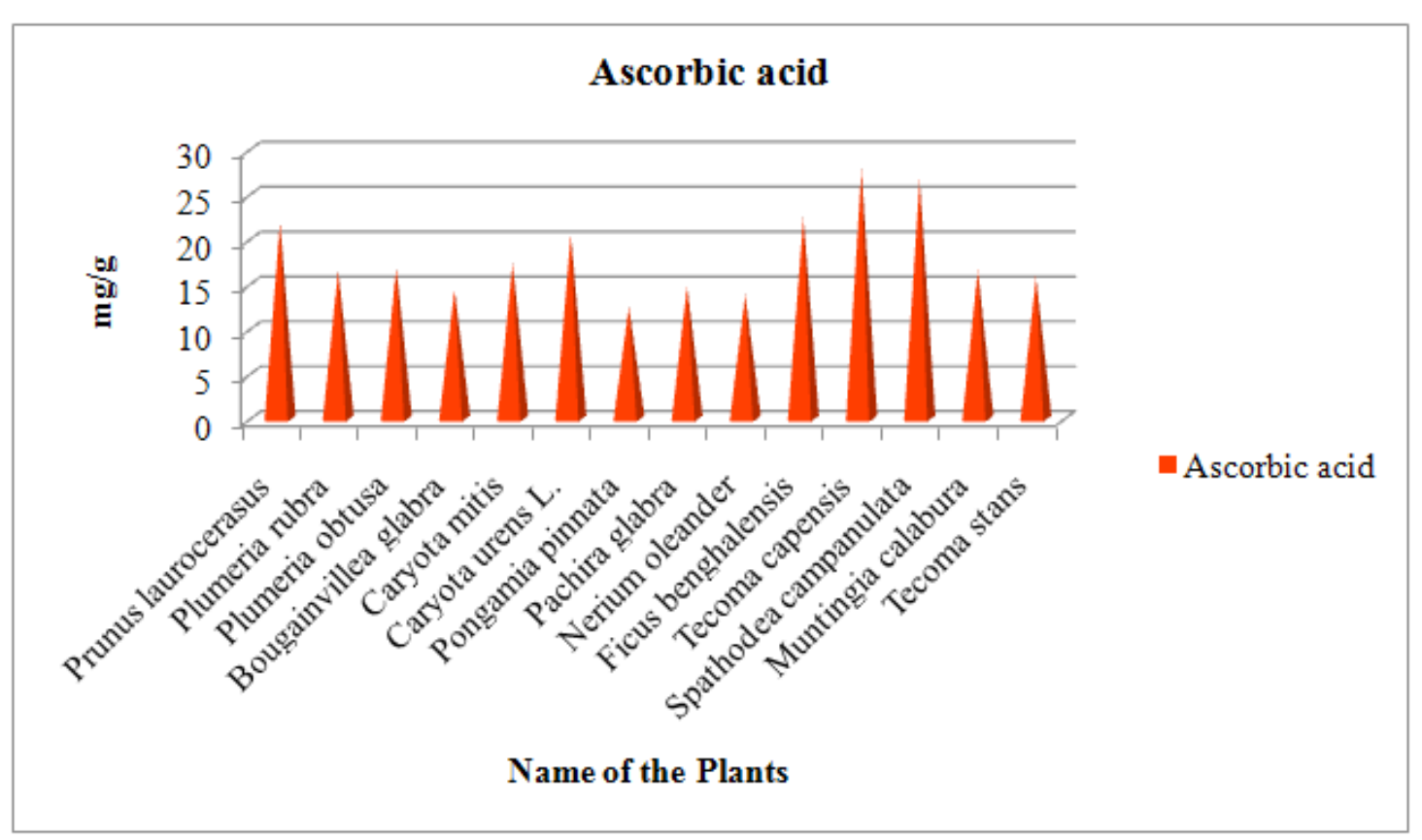

Graph 3. Ascorbic acid of the plant sample

Estimation of chlorophyll content: The total chlorophyll content was found to be in range of $14.72 \mathrm{mg} / \mathrm{g}$ to $68.72 \mathrm{mg} / \mathrm{g}$. In deciduous tree Plumeria rubra was found to be $27.03 \mathrm{mg} / \mathrm{g}$. In evergreen shrub the minimum chlorophyll content was found to be in Tecoma capensis in $14.72 \mathrm{mg} / \mathrm{g}$ where maximum chlorophyll content was found to be in Bougainvillea glabra in $68.72 \mathrm{mg} / \mathrm{g}$. In evergreen tree the minimum chlorophyll content was found to be in Spathodea campanulata in $17.35 \mathrm{mg} / \mathrm{g}$ and maximum chlorophyll content was found to be in Sterculia foetida $63.12 \mathrm{mg} / \mathrm{g}$ (Table 7; graph 4). 
Table 7: Total chlorophyll content of the leaf samples from the experimental site.

\begin{tabular}{|c|l|c|}
\hline S.No. & Name of the plant & Total chlorophyll mg/g \\
\hline 1. & Tabernaemontana divaricata & 44.81 \\
\hline 2. & Plumeria rubra & 27.03 \\
\hline 3. & Plumeria obtusa & 28.05 \\
\hline 4. & Bougainvillea glabra & 68.72 \\
\hline 5. & Caryota mitis & 50.13 \\
\hline 6. & Caryota urens L. & 43.24 \\
\hline 7. & Pongamia pinnata & 36.71 \\
\hline 8. & Sterculia foetida & 63.12 \\
\hline 9. & Nerium oleander & 26.19 \\
\hline 10. & Ficus benghalensis & 23.54 \\
\hline 11. & Tecoma capensis & 14.72 \\
\hline 12. & Spathodea campanulata & 17.35 \\
\hline 13. & Muntingia calabura & 22.59 \\
\hline 14. & Tecoma stans & 30.12 \\
\hline
\end{tabular}

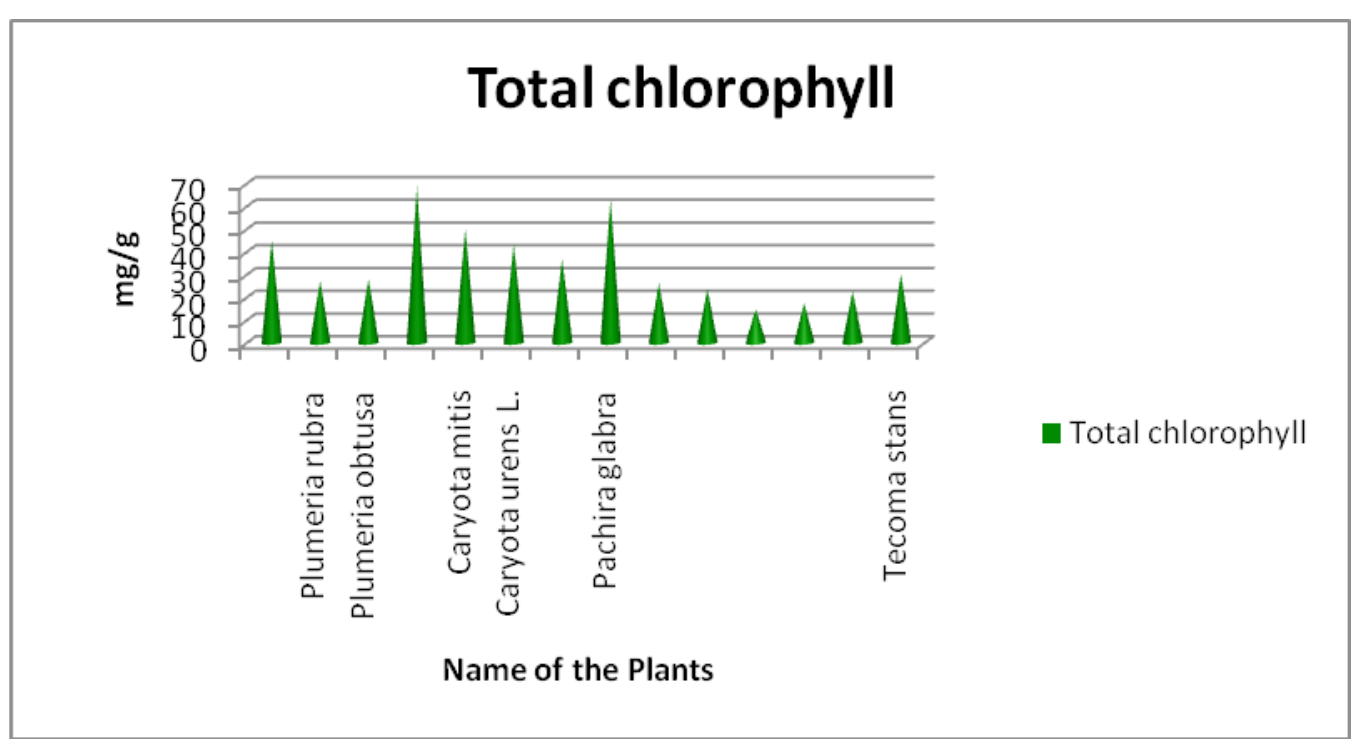

Graph 4. Total chlorophyll of the leaf samples

Air Pollution Tolerance Indices (APTI): The value ranged from 48.05 to 114.66 which reveals that the plant present in the experimental sites were all tolerant towards the vehicular emissions but the most tolerant plant was evergreen shrub compared to deciduous an evergreen tree. The deciduous tree showed the value of 62.38 and in evergreen shrub the APTI value was tolerable in all collected leaf samples but minimum in Nerium oleander with 48.05 and maximum in Tabernaemontana divaricata with 114.66. In evergreen tree the APTI value was minimum in Muntingia calabura with 48.47 and maximum value in Caryota urens with 108.97 (Table 8; Graph 5). 
Table 8: Air Pollution Tolerance Indices of the leaf samples from the experimental site.

\begin{tabular}{|c|l|c|}
\hline S.No. & Name of the Plants & APTI \\
\hline 1. & Tabernaemontana divaricata & 114.66 \\
\hline 2. & Plumeria rubra & 62.38 \\
\hline 3. & Plumeria obtusa & 63.35 \\
\hline 4. & Bougainvillea glabra & 102.35 \\
\hline 5. & Caryota mitis & 100.23 \\
\hline 6. & Caryota urens L. & 108.97 \\
\hline 7. & Pongamia pinnata & 55.09 \\
\hline 8. & Sterculia foetida & 105.00 \\
\hline 9. & Nerium oleander & 48.05 \\
\hline 10. & Ficus benghalensis & 74.99 \\
\hline 11. & Tecoma capensis & 64.91 \\
\hline 12. & Spathodea campanulata & 64.84 \\
\hline 13. & Muntingia calabura & 48.47 \\
\hline 14. & Tecoma stans & 61.23 \\
\hline
\end{tabular}

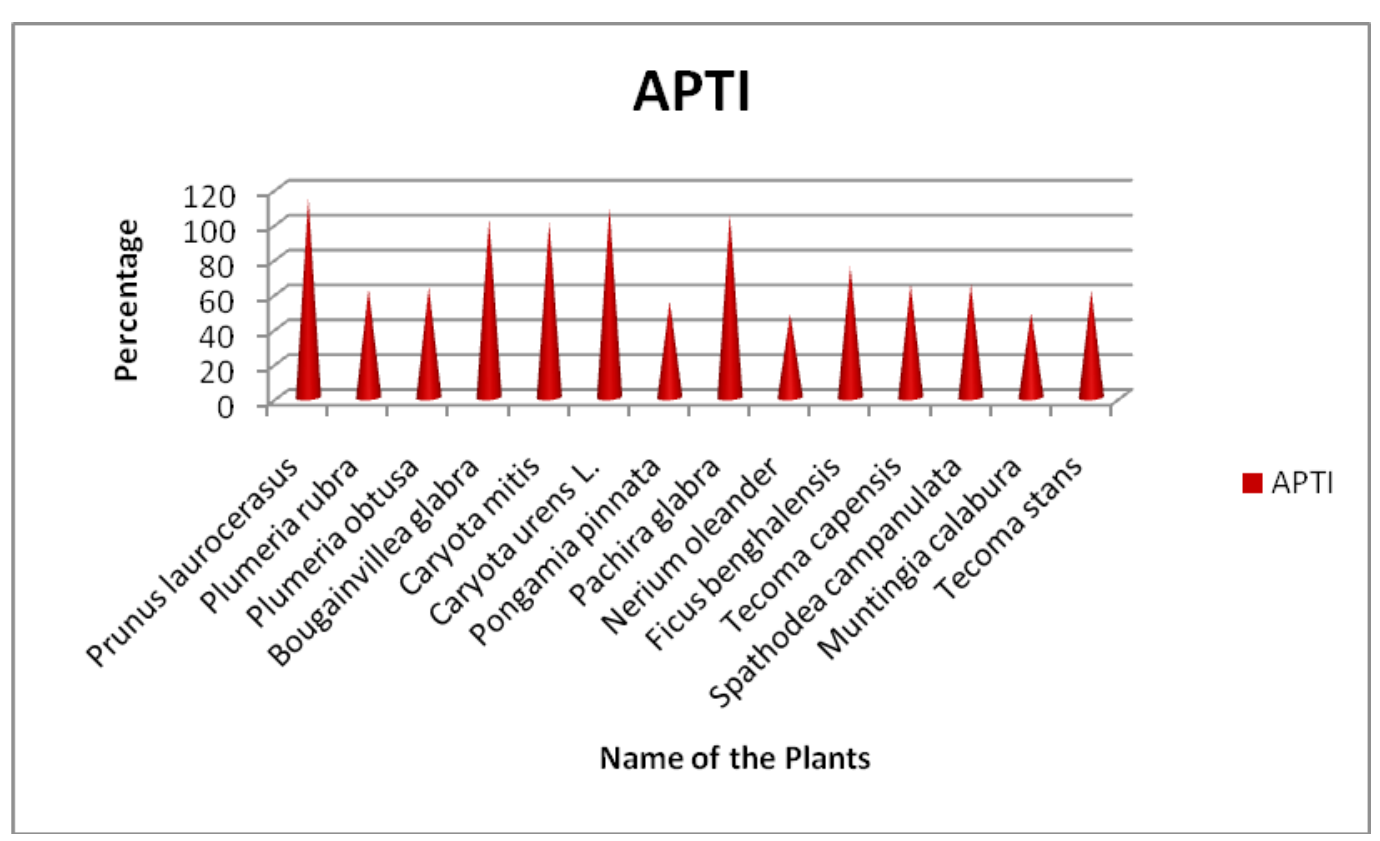

Graph 5. APTI of the leaf samples

\section{Conclusion}

The results of the present study revealed that vehicular emission in sholinganallur area are prevented by the plants present on the road side with good tolerance rate and among that evergreen shrub and evergreen tree can be planted more to prevent air pollution from these vehicular emission sites. Various biochemical parameters behaved differently in the studied plant species, however, ascorbic acid content was found to be the most crucial factor providing tolerance to the plants against air pollution. So, Tecoma capensis were found to be tolerant, and can be incorporated into a greenbelt design to assist the air pollution management practices.

\section{Ethical Clearance: Nil}

Source of Funding: Meenakshi Academy of Higher Education and Research, Chennai, India 


\section{Conflict of Interest: Nil}

\section{References}

1. Raabe OG. Respiratory exposure to air pollutants. Lung biology in health and disease. 1999;128:3973.

2. Radhapriya P, Gopalakrishnan AN, Malini P, Ramachandran A. Assessment of air pollution tolerance levels of selected plants around cement industry, Coimbatore, India. Journal of environmental biology. 2012 May 1;33(3):635641.

3. Odilara CA, Egwaikhide PA, Esekheigbe A, Emua SA. Air pollution tolerance indices (APTI) of some plant species around llupeju industrial area, Lagos. Journal of Engineering Science and applications. 2006;4(2):97-101.

4. Olukanni DO, Adebiyi SA. Assessment of vehicular pollution of road side soils in Ota Metropolis, Ogun State, Nigeria. International Journal of Civil \& Environmental Engineering IJCEE-IJENS. 2012;12(4):40-46.

5. Kisku GC, Pradhan S, Khan AH, Bhargava SK. Pollution in Lucknow City and its health implication on exposed vendors, drivers and traffic policemen. Air Quality, Atmosphere \& Health. 2013 Jun 1;6(2):509-515.

6. Kulshrestha UC, Sharma D. Importance of atmospheric dust in India: future scope of research. Journal of Indian Geophysical Union. 2015 Apr 1;19(2):205-209.

7. Cadle SH, Gorse, Jr RA, Bailey BK, Lawson DR. Real-world vehicle emissions: A summary of the twelfth Coordinating Research Council on-road vehicle emissions workshop. Journal of the Air \& Waste Management Association. 2003 Feb 1;53(2):152-167.

8. Arnon DI. Copper enzymes in isolated chloroplasts. Polyphenoloxidase in Beta vulgaris. Plant physiology. 1949 Jan;24(1):1-15.

9. Seyyednjad SM, Majdian K, Koochak H, Niknejad M. Air pollution tolerance indices of some plants around industrial zone in south of Iran. Asian Journal of biological sciences. 2011;4(3):300-305.

10. Chakraborty S, Solanki R, Dave J, Rana S, Kumar
$\mathrm{RN}$, Bhattacharya T. Effect of airborne fly ash deposition on morphology and biochemical parameters of Medicago sativa L. and Brassica juncea. Res Environ Life Sci. 2009;2:13-16.

11. Chavan BL, Sonwane NS. Anticipated Performance Index (API) of some tree species grown in Aurangabad city. International Journal for Environment Rehabilitation and Conservation. 2012;3(2):9-13.

12. Bell JN, Treshow M, editors. Air pollution and plant life. John Wiley \& Sons; 2002 May 22.

13. Priyanka C, Dibyendu B. Biomonitoring of air quality in the industrial town of asansol using the air pollution tolerance index approach. Res $\mathrm{J}$ Chem Environ. 2009 Mar 1;13(1):46-51.

14. Liu YJ, Ding HU. Variation in air pollution tolerance index of plants near a steel factory: Implication for landscape-plant species selection for industrial areas. WSEAS Transactions on Environment and development. 2008;4(1):24-32.

15. Gamble JS, Fischer CE. Flora of the Presidency of Madras. London, UK:: West, Newman and Adlard; 1915.

16. Krishnaveni M, Chandrasekar R, Amsavalli L, Madhaiyan P, Durairaj S. Air pollution tolerance index of plants at Perumalmalai hills, Salem, Tamil Nadu, India. International Journal of Pharmaceutical Sciences Review and Research. 2013;20(1):234-239.

17. Prasad BJ, Rao DN. Relative sensitivity of a leguminous and a cereal crop to sulphur dioxide pollution. Environmental Pollution Series A, Ecological and Biological. 1982 Sep 1;29(1):5770.

18. Sen DN, Bhandari MC. Ecological and water relation to two Citrullus spp. Indian Arid Zone. Environ. Physiol. Ecol. Plants. 1978:203-228.

19. Singh SK, Rao DN. Evaluation of plants for their tolerance to air pollution. InProceedings of symposium on air pollution control 1983 Nov (Vol. 1, pp. 218-224.

20. Tsega YC, Prasad AD. Variation in air pollution tolerance index and anticipated performance index of roadside plants in Mysore, India. Journal of Environmental Biology. 2014 Jan 1;35(1):185-190. 